\title{
Description the Importance of Developing a Self-Reliance Instrument for Schizophrenic Patients in the Hospital Setting
}

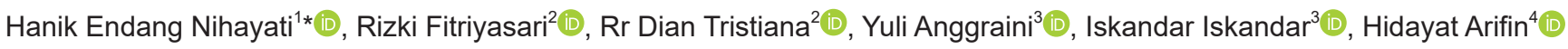 \\ ${ }^{1}$ Department of Advanced Nursing, Faculty of Nursing, Universitas Airlangga, Surabaya, Indonesia, ${ }^{2}$ Department of \\ Fundamental Nursing, Faculty of Nursing, Universitas Airlangga, Surabaya, Indonesia, ${ }^{3}$ Master in Nursing Study Program, \\ Faculty of Nursing, Universitas Airlangga, Surabaya, Indonesia, ${ }^{4}$ Department of Medical Surgical Nursing, Faculty of Nursing, \\ Universitas Padjadjaran, Bandung, Indonesia
}

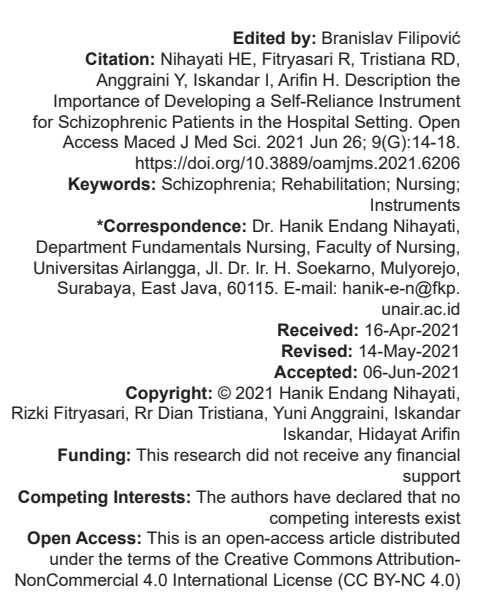

\begin{abstract}
BACKGROUND: The level of independence among schizophrenia patients is still a problem that must be resolved. The development of appropriate relevant instruments is needed.

AIM: This study aims to explore the needs and the importance of developing a self-reliance instrument for schizophrenic patients in the hospital setting.

METHODS: This study used a research and development study design. The study was conducted in a Psychiatric Hospital in Surabaya, Indonesia from August to December 2020. The total sample in this study consisted of 100 nurses determined by a simple random sampling technique. In addition, 50 medical records were observed. The inclusion criteria were nurses who cared for schizophrenia patients with a minimum work experience of 1 year Respondents were excluded from the study if they did not follow the study through to completion. The data collection process was done online by filling in a Google form. The data were analyzed using descriptive statistics and a focus group discussion (FGD) followed with ten nurses to discuss the new instrument.
\end{abstract}

RESULTS: The data found that a rehabilitation therapy instrument is not currently available (53\%). The FGD results show that it is necessary to develop the nurse's knowledge and to provide adequate facilities and wards, as well as to develop instruments to use as measuring tools in order to evaluate the rehabilitation therapy given.

CONCLUSION: Rehabilitation therapy instruments are important to develop for schizophrenia patients. It is hoped that the development of the instrument in this study will optimize the rehabilitation of schizophrenia patients.

\section{Introduction}

Schizophrenia is a mental disorder that causes interference when a person is thinking, feeling and behaving, and causing dependence [1]. The illness is commonly associated with impairments in social and occupational functioning [2]. The psychosocial problems faced by schizophrenia patients include not having work skills and being less able to be independent if they return to their family or the community. This means that they will remain a burden to their family and society [3], [4], [5]. The most severe condition among schizophrenia patients can lead to suicidal thoughts caused by the severity of the depressive symptoms that they experience [6]. Programs to increase the independence of schizophrenia patients need to be done. This can be done using the right instruments, so then the programs and policies that are appropriate can be targeted.

Schizophrenia occurs worldwide in about $1 \%$ of the population on an international scale. Meanwhile, the number of incidents (total new cases) totals around 1.5/10,000 residents [7]. In the study location, schizophrenia patients in 2019 reached 1166 in the emergency ward and 1458 in the inpatient ward [8]. Men are more likely to be diagnosed with schizophrenia than women (1.4:1) [9]. Problems related to the level of independence in schizophrenia patients can be caused by obesity factors in terms of triglyceride levels and lowdensity lipoprotein levels [10], family contact, and social participation [11]. The previous study reported most of schizophrenia patients have a high level of independency on treatment and daily activities [12], [13].

Studies conducted by several researchers show that rehabilitation therapy has an impact on the quality of life for schizophrenia patients and increases their level of independence [14], [15], [16]. Rehabilitation therapy is needed to improve the abilities of schizophrenia patients so then they are able to independently meet their self-care needs while also having a social life [17], [18]. Rehabilitation provides a route for optimal function and adjustment and prepares the clients physically, mentally, socially, and vocally for a full life in accordance with their abilities [19]. 
The rehabilitation of schizophrenia patients is very important to restore their individual rights and functions as independent and useful members of society and to increase their social skills in relation to both their family and society [20]. For this reason, it is necessary to improve the quality of the psychosocial rehabilitation instruments which will have an effect on the quality of life of people with mental disorders. It is, therefore, necessary to explore the needs and the importance of developing a self-reliance instrument for schizophrenic patients in the hospital setting.

\section{Materials and Methods}

This study is part of bigger study with research and development ( $R$ and $D)$ that consists of (1) identifying the problems (needs analysis, literature study, and expert discussion) related to implementation, followed by identifying any problems based on the needs analysis, literature study, and expert discussion related to implementation. (2) assessing the knowledge of the nurses in the hospital about rehabilitation, collected through the patient documents in the hospital in order to determine the strategic issues of nursing rehabilitation. (3) exploring the problems found through the focus group discussion (FGD). (4) preparing a rehabilitation instrument research plan. The study was used explanatory study design to develop an instrument. The study was conducted at a Psychiatric Hospital in Surabaya, Indonesia from August to December 2020.

The total sample in this study was 100 nurses who were determined using Lemeshow technique [21] and simple random sampling technique. In addition, 50 medical record documents were observed. The inclusion criteria were nurses who cared for schizophrenia patients with a minimum work experience of 1 year. Respondents were excluded from the study if they did not follow the study through to completion. The data collection process were done online by the respondents filling in the Google form. The data were analyzed using descriptive statistics followed by a FGD with 10 nurses to discuss the new instrument. This research has been declared to be ethical by the Health Research Ethics Commission of Menur Psychiatric Hospital in Surabaya, Indonesia, with number 070/14630/305/2020.

\section{Results}

The majority of respondents who participated in this study were women aged 25-29 years old. Most of the nurses have a diploma in nursing education with $5-10$ years and $>10$ years of work experience.
In addition, the majority of the participating nurses are associate nurses who have sufficient knowledge of rehabilitation therapy in schizophrenia patients despite rehabilitation therapy instruments not being available. The nurses gave a response indicating that it is important to develop a rehabilitation therapy instrument (Table 1).

Table 1: Respondent characteristics $(n=100)$

\begin{tabular}{|c|c|c|}
\hline Characteristic & $\mathrm{n}$ & $\%$ \\
\hline \multicolumn{3}{|l|}{ Gender } \\
\hline Male & 42 & 42 \\
\hline Female & 58 & 58 \\
\hline \multicolumn{3}{|l|}{ Age } \\
\hline $25-29$ years old & 30 & 30 \\
\hline $30-34$ years old & 26 & 26 \\
\hline $35-39$ years old & 21 & 21 \\
\hline $40-44$ years old & 11 & 11 \\
\hline$\geq 45$ years old & 12 & 12 \\
\hline \multicolumn{3}{|l|}{ Education } \\
\hline Diploma in nursing & 67 & 67 \\
\hline Bachelor's in nursing & 33 & 33 \\
\hline \multicolumn{3}{|l|}{ Length of work } \\
\hline$<5$ years & 24 & 24 \\
\hline $5-10$ years & 38 & 38 \\
\hline$>10$ years & 38 & 38 \\
\hline \multicolumn{3}{|l|}{ Position } \\
\hline Associate nurse & 81 & 81 \\
\hline Nurse unit manager & 19 & 19 \\
\hline \multicolumn{3}{|l|}{ Knowledge } \\
\hline Good & 9 & 9 \\
\hline Enough & 58 & 58 \\
\hline Less & 33 & 33 \\
\hline \multicolumn{3}{|c|}{ There is a rehabilitation therapy instrument in the ward } \\
\hline Available & 47 & 47 \\
\hline Not available & 53 & 53 \\
\hline \multicolumn{3}{|c|}{ The importance of rehabilitation therapy instruments in nursing } \\
\hline Very important & 34 & 34 \\
\hline Important & 58 & 58 \\
\hline Enough & 8 & 8 \\
\hline
\end{tabular}

Table 2 shows that the main nursing problem is violence with signs of anger. The data show that the majority of data on the implementation of rehabilitation therapy is not documented.

Table 2: Medical record evaluation and the nurse's opinion of rehabilitation therapy when nursing $(n=50)$

\begin{tabular}{lll}
\hline Indicator & $\mathrm{n}$ & $\%$ \\
\hline Nursing problems & & \\
$\quad$ Violence & 25 & 50 \\
$\quad$ Hallucinations & 21 & 42 \\
$\quad$ Delusion & 4 & 8 \\
Symptom & & 50 \\
$\quad$ Angry & 25 & 42 \\
$\quad$ Talk digresses & 21 & 8 \\
$\quad$ Suspicious and sad & 4 & \\
Rehabilitation carried out & 6 & 12 \\
$\quad$ Day 7 & 9 & 18 \\
Day <14 & 9 & 18 \\
$\quad$ Day >14 & 26 & 52 \\
$\quad$ No documentation & & 32 \\
Nursing rehabilitation therapy performed & 16 & 24 \\
$\quad$ In-ward therapy & 12 & 44 \\
$\quad$ Outside the ward & 22 & \\
No documentation & & \\
\hline
\end{tabular}

The recommendations from the FGD regarding increasing the knowledge and ability of nurses when implementing rehabilitation therapy in nursing in the ward are as follows: (1) it is necessary to develop the knowledge and ability of the nurses when implementing rehabilitation therapy when nursing in the patient's ward. (2) it is necessary to develop a method to optimize the implementation of any necessary documentation and the implementation of rehabilitation therapy when nursing in the ward. (3) it is necessary to develop rehabilitation therapy instruments for nursing based on either the literature or evidence. (4) tghe existence of rehabilitation therapy instruments in nursing will 
greatly help the nurses in the ward to optimise the implementation of rehabilitation therapy when nursing in the ward so then they can prepare the patients to go home optimally. (5) expert consultation is needed to obtain input on the results of the literature studies, on the study of the patient documentation in the field, and on the results of the FGD. It is hoped that expert discussions will provide an input when developing rehabilitation therapy instruments for use when nursing in the ward (Table 3).

\section{Discussion}

The knowledge of rehabilitation therapy is an important factor that the nurses must consider when treating patients with schizophrenia [22]. This is so then the therapy given is in accordance with the goals and needs of the patient. Not only that, with the right knowledge and therapy, it can speed up the patient's healing process. The goal of therapeutic rehabilitation is to help the patients return to a level of normalcy, to survive, and to improve on the skills needed in everyday life. This form of therapy includes their physical, mental, and cognitive abilities [23]. Previous research states that the knowledge possessed by the nurses is very important in order for them to be able to provide interventions and therapeutic approaches to schizophrenia patients [24], [25], [26]. The nurses thus become very effective therapy providers and counselors for the patients. This is because the nurse knows about the patient's condition.
Furthermore, from this study, we found that an appropriate place for implementing rehabilitation therapy for schizophrenia patients is needed. The right place can provide comfort for the patients [20]. Besides that, schizophrenia patients with difficulty focusing become a problem if the rehabilitation therapy is not given in the right place. Some studies suggest that schizophrenia therapy can be done in a ward that is not too crowded so then the patients can focus on the therapy given. In addition, therapy can be carried out at outdoors. Rehabilitation therapy places must adjust to the type and needs of the patient [20], [27], [28]. The right place to provide the therapy is important and this can increase the success of the rehabilitation therapy itself. With sufficient space, atmosphere, and equipment, it can increase the patient's ability to benefit from the therapy given.

To achieve success in terms of the rehabilitation therapy, an evaluation instrument is needed. In this study, the nurses did not yet have available any rehabilitation therapy instruments to evaluate the success of the given therapy. The available information related the rehabilitation only take a note on nursing care assessment consist of ability, responsibility, behavior, and cooperation of patients during schizophrenia intervention. The instrument intended is a measuring tool to determine the progress of the patient, so then the data can be integrated with the progress notes used in their care. The previous research states that instruments in rehabilitation therapy are important for achieving and evaluating the development of schizophrenia patients [29], [30]. The instructions made must be created in accordance with the evidence-based on the patient.

This study provides information on the results of the FGD which provides suggestions for

Table 3: The results of the FDG used to develop a nursing rehabilitation therapy instrument to increase the independence of schizophrenia patients

\begin{tabular}{|c|c|c|c|}
\hline Strategic issue & Causes & Result & Research \\
\hline $\begin{array}{l}\text { Knowledge of nurses in } \\
\text { rehabilitation which is } \\
\text { not optimal because the } \\
\text { previous data shows that } \\
\text { the knowledge of nurses is } \\
\text { in enough category }\end{array}$ & $\begin{array}{l}\text { 1. Rehabilitation therapy training does not cover all } \\
\text { nurses in the inpatient ward of the Psychiatric } \\
\text { Hospital } \\
\text { 2. Differences in the perception of the nurses } \\
\text { regarding the implementation of rehabilitation } \\
\text { therapy for the patients } \\
\text { 3. There are no instruments and guidelines related } \\
\text { to rehabilitation therapy when nursing in the ward }\end{array}$ & $\begin{array}{l}\text { 1. It is necessary to conduct rehabilitation } \\
\text { therapy training for the nurses on the } \\
\text { independence of schizophrenia patients } \\
\text { 2. It is necessary to have the same perception } \\
\text { across the nurses in the implementation of } \\
\text { rehabilitation therapy when nursing } \\
\text { 3. The need for rehabilitation therapy } \\
\text { instruments in nursing }\end{array}$ & $\begin{array}{l}\text { 1. Organising in-house training related to the } \\
\text { implementation of rehabilitation therapy } \\
\text { 2. Nurses who have received training disseminate } \\
\text { the information to all nurses in the ward, so then } \\
\text { they have the same perception } \\
\text { 3. The nursing team needs to develop instruments } \\
\text { related to the guidance for implementing the } \\
\text { rehabilitation therapy }\end{array}$ \\
\hline $\begin{array}{l}\text { The rehabilitation therapy in } \\
\text { nursing that is carried out in } \\
\text { the ward is not optimal }\end{array}$ & $\begin{array}{l}\text { 1. The nurses are not used to assessing patients } \\
\text { concerning their time in rehabilitation } \\
\text { 2. There are no clear rules for filling in the patient } \\
\text { instruments used for rehabilitation in nursing }\end{array}$ & $\begin{array}{l}\text { 1. There are rehabilitation therapy instruments } \\
\text { to be filled in by the nurses related to the } \\
\text { rehabilitation of the patients } \\
\text { 2. Establishing regulations for patients who are } \\
\text { moved to the maintenance ward (preparation } \\
\text { for going home) as soon as possible in order } \\
\text { to carry out the rehabilitation therapy }\end{array}$ & $\begin{array}{l}\text { 1. The Head of the Ward increases the supervision } \\
\text { related to the implementation of the nursing } \\
\text { rehabilitation therapy } \\
\text { 2. The nursing team establishes a more operational } \\
\text { policy to optimise the implementation and } \\
\text { documentation of the implementation of } \\
\text { rehabilitation therapy in the ward }\end{array}$ \\
\hline $\begin{array}{l}\text { Most of the nurses want an } \\
\text { instrument when engaging } \\
\text { in rehabilitation therapy in } \\
\text { the ward }\end{array}$ & $\begin{array}{l}\text { 1. The ward nurses feel the need for instruments for } \\
\text { the implementation of rehabilitation therapy when } \\
\text { nursing in the ward } \\
\text { 2. So far, the implementation of rehabilitation } \\
\text { therapy is carried out outside of the ward related } \\
\text { to the talents and hobbies of the patient }\end{array}$ & $\begin{array}{l}\text { 1. It is necessary to develop standard } \\
\text { instruments that are filled in by the nurses so } \\
\text { then the implementation of the rehabilitation } \\
\text { therapy in the ward can run optimally } \\
\text { 2. The implementation of rehabilitation therapy } \\
\text { in the confinement of the ward is carried out } \\
\text { as soon as possible in order to prepare for } \\
\text { optimal patient discharge }\end{array}$ & $\begin{array}{l}\text { 1. The nursing team needs to revise and develop } \\
\text { instruments on nursing to carry out rehabilitation } \\
\text { in the ward } \\
\text { 2. There needs to be a common perception } \\
\text { through socialization for the implementation of } \\
\text { rehabilitation therapy in the ward }\end{array}$ \\
\hline $\begin{array}{l}\text { plementation of } \\
\text { litation therapy in the }\end{array}$ & $\begin{array}{l}\text { 1. There is no planned evaluation of the } \\
\text { implementation of rehabilitation therapy in the } \\
\text { confinement of the ward } \\
\text { 2. There is no distribution and rehabilitation therapy } \\
\text { guide on nursing in the ward } \\
\text { 3. There was found to be an unavailability of } \\
\text { rehabilitation therapy instruments for nursing in } \\
\text { the ward }\end{array}$ & $\begin{array}{l}\text { 1. It is necessary to evaluate the } \\
\text { implementation of the rehabilitation therapy } \\
\text { in the ward } \\
\text { 2. Ensure that each ward has SOPs and } \\
\text { guidelines for implementing the rehabilitation } \\
\text { therapy } \\
\text { 3. Each ward provides an instrument form for } \\
\text { implementing the rehabilitation therapy }\end{array}$ & $\begin{array}{l}\text { 1. The nursing team will create an evaluation } \\
\text { schedule for the implementation of rehabilitation } \\
\text { therapy in the ward } \\
\text { 2. The nursing team collaborates with the nursing } \\
\text { quality assurance to distribute SOPs for the } \\
\text { purpose of implementing the rehabilitation therapy } \\
\text { 3. Each ward ensures the availability of rehabilitation } \\
\text { therapy instrument forms }\end{array}$ \\
\hline
\end{tabular}


the development of nursing instruments for use in rehabilitation therapy for schizophrenia patients. However, this research is still limited to concept development. The arrangement of the instruments in accordance with the evidence using qualitative study and validity and reliability testing is required. In the future, nursing instruments in rehabilitation therapy should be implemented.

\section{Conclusion}

This study provides important results as part of the information to developing rehabilitation therapy instruments needs in nursing. This is in accordance with the results of the FGD which suggested that the formation of an instrument is necessary as a medium for evaluating rehabilitation therapy in the treatment of schizophrenia patients. Not only that, but other factors also such as the place of rehabilitation need to be considered concerning the success of the therapy given. Rehabilitation therapy can be done optimally if it is supported by the good knowledge of the nurse. For this reason, cooperation from both the hospitals and nurses involved is needed in order to be able to develop rehabilitation therapy by increasing the knowledge of the nurses, by providing adequate facilities and wards, as well as utilizing instruments as measuring tools to evaluate the rehabilitation therapy given.

\section{Availability of the Data and Materials}

The datasets used and/or analyzed during the current study are available from the corresponding author upon receipt of a reasonable request.

\section{Acknowledgment}

We express our deepest gratitude to all of the respondents and the hospital who helped and participated in this study.

\section{References}

1. Moncrieff J, Crellin NE, Long MA, Cooper RE, Stockmann T. Definitions of relapse in trials comparing antipsychotic maintenance with discontinuation or reduction for schizophrenia spectrum disorders: A systematic review. Schizophr Res. 2020;225:47-54. https://doi.org/10.1016/j.schres.2019.08.035 PMid:31604607

2. Diagnostic and Statistical Manual of Mental Disorders (DSM-5). $5^{\text {th }}$ ed. Arlington: American Psychiatric Association; 2013. https:// doi.org/10.1007/springerreference_179660

3. Fortgang RG, Hoff RA, Potenza MN. Schizophrenia symptom severity and motivations for gambling in individuals with schizophrenia or schizoaffective disorder. Psychiatry Res. 2020;291:113281. https://doi.org/10.1016/j. psychres.2020.113281

PMid:32763543

4. Shah D, Knott V, Baddeley A, Bowers H, Wright $\mathrm{N}$, Labelle $\mathrm{A}$, et al. Impairments of emotional face processing in schizophrenia patients: Evidence from P100, N170 and P300 ERP components in a sample of auditory hallucinators. Int $J$ Psychophysiol. 2018;134:120-34. https://doi.org/10.1016/j. ijpsycho.2018.10.001

PMid:30291891

5. Chen J, Chen X, Leung SS, Tsang HW. Potential impacts, alleviating factors, and interventions for children of a parent with schizophrenia: A scoping review. Child Youth Serv Rev. 2021;120:105751. https://doi.org/10.1016/j. childyouth.2020.105751

6. Zhong Y, Xia L, Zhao TT, Zhang YL, Zhang YL, Li WZ, et al. The prevalence of suicide attempts and independent demographic and clinical correlates among chronic schizophrenia patients in agricultural areas of china. Psychiatr Q. 2019;90(4):683-91. https://doi.org/10.1007/s11126-019-09644-1

PMid:31102121

7. McGrath J, Saha S, Chant D, Welham J. Schizophrenia: A concise overview of incidence, prevalence, and mortality. Epidemiol Rev. 2008;30:67-76. https://doi.org/10.1093/epirev/ mxn001 PMid:18480098

8. Ika I. Saat Ini Ada 21 Ribu Pasien Skizofrenia di Surabaya 2019. Available from: https://www.jpnn.com/news/ saat-ini-ada-21-ribu-pasien-skizofrenia-di-surabaya?page=1 .

9. Abel KM, Drake R, Goldstein JM. Sex differences in schizophrenia. Int Rev Psychiatry. 2010;22(5):417-28. PMid:21047156

10. Wang J, Zhang Y, Yang Y, Liu Z, Xia L, Li W, et al. The prevalence and independent influencing factors of obesity and underweight in patients with schizophrenia: A multicentre crosssectional study. Eat Weight Disord. 2021;26(5):1365-74. https:// doi.org/10.1007/s40519-020-00920-9 PMid:32557379

11. Dickerson FB, Ringel N, Parente F. Predictors of residentia independence among outpatients with schizophrenia. Psychiatr Serv. 1999;50(4):515-9. https://doi.org/10.1176/ps.50.4.515 PMid:10211733

12. Bornstein RF. The Dependent Patient: A Practitioner's Guide. United States: American Psychological Association; 2005.

13. Geurtzen N, Keijsers GPJ, Karremans JC, Hutschemaekers GJ. Patients' care dependency in mental health care: Development of a self-report questionnaire and preliminary correlates. J Clin Psychol. 2018;74(7):1189-206. https://doi.org/10.1002/ jclp.22574

PMid:29319187

14. Desalegn D, Girma S, Abdeta T. Quality of life and its association with psychiatric symptoms and socio-demographic characteristics among people with schizophrenia: A hospitalbased cross-sectional study. PLoS One. 2020;15(2):e0229514. https://doi.org/10.1371/journal.pone.0229514

PMid:32092123 
15. Cernovsky Z. Quality of life in persons with schizophrenia. Ment IIIn. 2017;9(1):7052.

PMid:28435648

16. Durgoji S, Muliyala KP, Jayarajan D, Chaturvedi SK. Quality of life in schizophrenia: What is important for persons with schizophrenia in India? Indian J Psychol Med. 2019;41(5):4207. https://doi.org/10.4103/ijpsym.ijpsym_71_19 PMid:31548764

17. Maryatun S. Peningkatan kemandirian perawatan diri pasien skizofrenia melalui rehabilitasi terapi gerak (Increasing patient self-care independence schizophrenia through motion therapy rehabilitation). J Keperawatan Sriwij. 2015;2(2):108-14.

18. Rosmini R, Sutria E, Wahdaniah W. Intervention of nurse deficit self care in the skizofrenia patient: Systematic review. J Nurs Pract. 2020;3(2):244-52. https://doi.org/10.30994/jnp.v3i2.94

19. Glynn SM. The challenge of psychiatric rehabilitation in schizophrenia. Curr Psychiatry Rep. 2001;3(5):401-6. PMid: 11559477

20. Morin L, Franck N. Rehabilitation interventions to promote recovery from schizophrenia: A systematic review. Front Psychiatry. 2017;8:100. https://doi.org/10.3389/fpsyt.2017.00100 PMid:28659832

21. Lemeshow S, Hosmer DW, Klar J, Lwanga SK. Adequacy of Sample Size in Health Studies. New York: Jogn Wiley and Sons; 1991. https://doi.org/10.1002/bimj.4710330419

22. Jones CA, Roop SC, Pohar SL, Albrecht L, Scott SD. Translating knowledge in rehabilitation: Systematic review. Phys Ther. 2015;95(4):663-77. https://doi.org/10.2522/ptj.20130512 PMid:24903114

23. Kamo T, Momosaki R, Suzuki K, Asahi R, Azami M, Ogihara $\mathrm{H}$, et al. Effectiveness of intensive rehabilitation therapy on functional outcomes after stroke: A propensity score analysis based on japan rehabilitation database. J Stroke Cerebrovasc Dis. 2019;28(9):2537-42. https://doi.org/10.1016/j. jstrokecerebrovasdis.2019.06.007
PMid:31235378

24. Velligan DI, Gonzalez JM. Rehabilitation and recovery in schizophrenia. Psychiatr Clin North Am. 2007;30(3):535-48. PMid:17720035

25. Gaigl G, Täumer E, Merz K, Zöscher S, Wagner S, Kösters M, et al. Multifactorial barriers in the implementation of schizophrenia and psychosocial therapies guidelines: A quantitative study across different professions. Schizophr Res. 2021;228:425-34. https://doi.org/10.1016/j.schres.2021.01.010 PMid:33561620

26. Moore JL, Mbalilaki JA, Graham ID. Knowledge translation in physical medicine and rehabilitation: A citation analysis of the knowledge-to-action literature. Arch Phys Med Rehabil. 2021:S0003-9993(21)00144-1. https://doi.org/10.1016/j. apmr.2020.12.031

27. RajeswaranJ, Taksal A, Jain S. Reha bilitation in schizophrenia: A brain-behavior and psychosocial perspective. Indian J Psychol Med. 2017;39(6):797-9. https://doi. org/10.4103/0253-7176.219648 PMid:29284815

28. Loh SY. Interdisciplinary Rehabilitation to Facilitate Recovery of People Living with Long-Term Schizophrenia in Developing Countries. Psychotic Disorders. London: InTech; 2018. https:// doi.org/10.5772/intechopen.75548

29. Wan FJ, Chien WC, Chung CH, Yang YJ, Tzeng NS. Association between traumatic spinal cord injury and affective and other psychiatric disorders-a nationwide cohort study and effects of rehabilitation therapies. J Affect Disord. 2020;265:381-8. https:// doi.org/10.1016/j.jad.2020.01.063 PMid:32090763

30. Rodriguez-Villa E, Camacho E, Torous J. Psychiatric rehabilitation through teaching smartphone skills to improve functional outcomes in serious mental illness. Internet Interv. 2021;23:100366. https://doi.org/10.1016/j.invent.2021.100366 PMid:33532245 